\title{
Liraglutide and sitagliptin counter beta- to alpha-cell transdifferentiation in diabetes
}

\author{
Neil Tanday, Peter R Flatt, Nigel Irwin and R Charlotte Moffett \\ SAAD Centre for Pharmacy and Diabetes, Ulster University, Coleraine, Northern Ireland, UK
}

Correspondence should be addressed to N Irwin: n.irwin@ulster.ac.uk

\begin{abstract}
Transdifferentiation of beta- to alpha-cells has been implicated in the pathogenesis of diabetes. To investigate the impact of contrasting aetiologies of beta-cell stress, as well as clinically approved incretin therapies on this process, lineage tracing of beta-cells in transgenic Ins 1 Cre/t/Rosa26-eYFP mice was investigated. Diabetes-like syndromes were induced by streptozotocin (STZ), high fat feeding (HFF) or hydrocortisone (HC), and effects of treatment with liraglutide or sitagliptin were investigated. Mice developed the characteristic metabolic features associated with beta-cell destruction or development of insulin resistance. Liraglutide was effective in preventing weight gain in HFF mice, with both treatments decreasing energy intake in STZ and HC mice. Treatment intervention also significantly reduced blood glucose levels in STZ and HC mice, as well as increasing either plasma or pancreatic insulin while decreasing circulating or pancreatic glucagon in all models. The recognised changes in pancreatic morphology induced by STZ, HFF or HC were partially, or fully, reversed by liraglutide and sitagliptin, and related to advantageous effects on alpha- and beta-cell growth and survival. More interestingly, induction of diabetes-like phenotype, regardless of pathogenesis, led to increased numbers of beta-cells losing their identity, as well as decreased expression of Pdx 1 within beta-cells. Both treatment interventions, and especially liraglutide, countered detrimental islet cell transitioning effects in STZ and HFF mice. Only liraglutide imparted benefits on beta- to alpha-cell transdifferentiation in $\mathrm{HC}$ mice. These data demonstrate that beta- to alpha-cell transdifferentiation is a common consequence of beta-cell destruction or insulin resistance and that clinically approved incretin-based drugs effectively limit this.
\end{abstract}

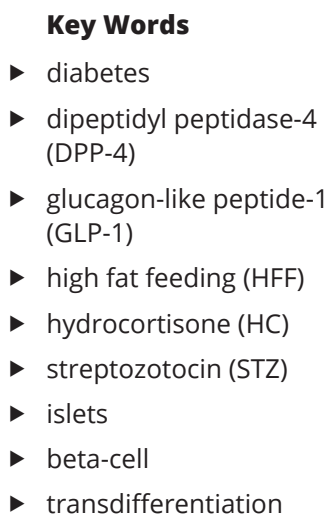

Journal of Endocrinology (2020) 245, 53-64

\section{Introduction}

The pathogenesis of diabetes is complex, involving many processes that ultimately results in pancreatic beta-cell dysfunction and/or development of peripheral insulin resistance (Weir \& Bonner-Weir 2004). The deficit of betacell mass and function in diabetes is not well understood and has been linked to a loss of beta-cell identity, but related mechanism proves difficult to investigate (Accili et al. 2010, Kitamura 2013). However, recent advances in cell lineage tracing technologies has shed light on the process of pancreatic beta-cells transitioning from their mature state to become dedifferentiated or transdifferentiated into other cell types (Collombat et al. 2007, 2009, Thorel et al. 2010, Huising et al. 2018). As such, beta-cell dedifferentiation is defined as a loss of beta-cell components, usually associated with an increase in the expression of progenitor markers, resulting in 
reduced insulin secretion (Weir et al. 2013). The related process of transdifferentiation is generally categorised as a fully differentiated islet cell, such as a beta-cell, losing its phenotype and converting to an entirely new islet endocrine like cell (Talchai et al. 2012, Rutter et al. 2015). This process can occur directly, when an islet cell demonstrates a second hormone before losing expression of its initial hormone, or indirectly whereby an intermediate dedifferentiation stage occurs prior to transition to a new islet cell (van der Meulen \& Huising 2015).

Extreme experimental conditions can been used to provoke and study transdifferentiation of islet cells in rodents. This includes chemically induced beta-cell ablation (Thorel et al. 2010) or through altering the expression of specific islet cell transcription factors such as aristaless-related homeobox (Arx) (Courtney et al. 2013), paired box gene 4 (Pax4) (Collombat et al. 2007), pancreatic and duodenal homeobox 1 (Pdx-1) or forkhead box O1 (FOXO1) (Talchai et al. 2012). Expression of such transcription factors are known to be vital in maintaining differentiated islet cell phenotypes (Gu et al. 2010, Hart et al. 2013, Gao et al. 2014, Taylor et al. 2015). As such, natural loss of beta-cell FOXO1 expression during aging results in increased susceptibility to diabetes due to betacell dedifferentiation (Kitamura et al. 2013). Importantly, these processes are not restricted to rodents, with dedifferentiation and transdifferentiation being observed in vitro in human beta-cells (Gershengorn et al. 2004, Weinberg et al. 2007, Spikjer et al. 2015, Diedisheim et al. 2018) and in islet cells harvested directly from type 2 diabetes mellitus (T2DM) patients (Cinti et al. 2016).

In this regard, beneficial effects of the incretin hormones, glucagon-like peptide-1 (GLP-1) and glucosedependent insulinotropic polypeptide (GIP), in T2DM have been linked to direct positive effects at the level of the endocrine pancreas. This includes, but not limited to, potentiation of glucose-stimulated insulin secretion, promotion of beta-cell growth, protection of beta cells from apoptosis and, in the case of GLP-1, suppression of glucagon secretion (Mest et al. 2005, Baggio \& Drucker 2007). In addition, incretin peptides have been shown to upregulate expression levels of islet cell transcription factors involved in maintenance of beta-cell identity (Wei \& Hong 2019). Thus, preliminary studies have examined the effects of GLP-1, but not GIP, on islet cell transdifferentiation in diabetes (Wei \& Hong 2019), with suggestion of favourable outcomes. To fully address this concept, the current study has employed transgenic

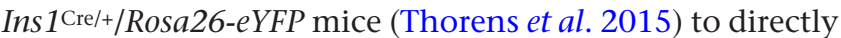

investigate beta- to alpha-cell transdifferentiation under contrasting diabetes-like aetiologies, including multiple low-dose streptozotocin (STZ) or hydrocortisone (HC) administration, as well as prolonged high fat feeding. In addition, we also explored the impact of pharmacological upregulation of incretin receptor signalling pathways in each rodent model, through sub-chronic administration of the clinically approved GLP-1 receptor agonist, liraglutide, or the didpeptidyl peptidase-4 (DPP-4) inhibitor, sitagliptin. Together these studies unequivocally demonstrate the consequence of diabetes on islet cell differentiation and the potential beneficial role of incretin receptor signalling on these processes.

\section{Materials and methods}

\section{Animals}

Ins $1^{\text {Cre/+/Rosa26-eYFP C57BL/6 mice (Jackson Laboratories) }}$ were bred in house at the Biomedical and Behavioural Research Unit (BBRU) at Ulster University, Coleraine. The original background of these mice has been characterised by Thorens et al. (2015). Mice were housed individually in a temperature controlled room $\left(22 \pm 2^{\circ} \mathrm{C}\right)$ on a regular 12-h light/dark cycle. Standard chow (Trouw Nutrition, Norwich, UK) and drinking water were available ad libitum. All in vivo experiments were approved by Ulster University Animal Ethics Review Committee and conducted in accordance to the UK Animals (Scientific Procedures) Act 1986. Diabetes-like symptoms were induced in male mice $(n=6)$ using STZ, HC or high fat feeding.

Our studies were appropriately powered $(n=6)$ to ensure robust and reproducible findings, using minimal numbers of animals, in line with the guiding principles of more ethical use of animals in research. In brief, STZ ( $50 \mathrm{mg} / \mathrm{kg}$ ) was given to 12 -week-old mice on 5 consecutive days by intraperitoneal (i.p.) injection in citrate buffer, inducing symptoms of insulin deficiency 5 days after the final injection. HC (70 $\mathrm{mg} / \mathrm{kg})$ was administered to 12-week-old mice on 10 consecutive days by i.p. injection, to induce insulin resistance. In both models, twice daily i.p. administration of liraglutide $(25 \mathrm{nmol} / \mathrm{kg})$ or once daily oral administration of sitagliptin (50 mg/ $\mathrm{kg}$ ) was commenced 2-3 days prior to administration of STZ or $\mathrm{HC}$ and continued until the end of the respective study period. For high-fat feeding studies, 4-week-old mice were maintained on a high-fat diet (45\% fat) until 15 weeks of age to induce obesity and insulin resistance. These mice were similarly dosed with liraglutide $(25 \mathrm{nmol} / \mathrm{kg}$, i.p.; BID) or sitagliptin (50 mg/kg, p.o.) for an additional 
12 days. The doses of liraglutide and sitagliptin were selected on the basis of previous studies (Gault et al. $2015 a$, O'Harte et al. 2018). For all studies, groups of 6-8 mice were used together with appropriate saline-treated controls. Body weight, energy intake and non-fasting blood glucose were determined at regular intervals. Energy intake was assessed by manually determining consumption of respective diet for each mouse, and then using $\mathrm{kJ} / \mathrm{g}$ energy content to extrapolate energy intake. Blood glucose measured from a tail vein blood spot using an Ascencia Contour Blood Glucose metre (Bayer Healthcare, Newbury, UK). Terminal blood samples were taken for biochemical analyses and immunohistochemistry.

\section{Biochemical analyses}

Snap frozen pancreatic tissues were homogenised in acid ethanol (ethanol $(75 \%(\mathrm{v} / \mathrm{v})$ ethanol, 5\% (v/v) distilled water and $1.5 \%(\mathrm{v} / \mathrm{v}) 12 \mathrm{~N} \mathrm{HCl})$ ) and protein extracted in a pH neutral TRIS buffer. Protein content was determined using Bradford reagent (Sigma-Aldrich). Plasma and pancreatic insulin content was determined by an in-house insulin RIA (Flatt \& Bailey 1981). Plasma and pancreatic glucagon content was determined by ELISA (glucagon chemiluminescent assay, EZGLU-30K, Millipore) following the manufacturer's guidelines.

\section{Immunohistochemistry}

Upon termination of studies, pancreatic tissues were excised and fixed in $4 \%$ PFA for $48 \mathrm{~h}$ at $4^{\circ} \mathrm{C}$ (Gault et al. $2015 b$ ). Tissues were processed and embedded in paraffin wax blocks using an automated tissue processor (Leica TP1020, Leica Microsystems) and $5 \mu \mathrm{m}$ sections were cut on a microtome (Shandon finesse 325, Thermo Scientific). For immunohistochemistry, slides were dewaxed by immersion in xylene and rehydrated through a series of ethanol solutions (100-50\%). Heat-mediated antigen retrieval was then carried out in citrate buffer. Sections were blocked in $4 \%$ BSA solution before $4^{\circ} \mathrm{C}$ overnight incubation with the following primary antibodies (Table 1), as appropriate, mouse monoclonal anti-insulin (ab6995, 1:400; Abcam), guinea-pig anti-glucagon (PCA2/4, 1:400; raised in-house), rabbit anti-Ki-67 (ab15580, 1:500; Abcam), rabbit anti-Pdx1 (ab47267, 1:200; Abcam) and goat anti-GFP antibody (ab5450, 1:1000; Abcam). Following this, slides were rinsed in PBS and incubated for $45 \mathrm{~min}$ at $37^{\circ} \mathrm{C}$ with appropriate secondary antibodies (Table 1) including, Alexa Fluor 488 goat anti-guinea pig IgG, Alexa Fluor594 goat anti-mouse IgG, Alexa Fluor488 goat anti-rabbit IgG, Alexa Fluor594 goat anti-rabbit IgG or Alexa Fluor488 donkey anti-goat IgG. Slides were finally incubated with DAPI for $15 \mathrm{~min}$ at $37^{\circ} \mathrm{C}$, and then mounted for imaging using a fluorescent microscope (Olympus model BX51) fitted with DAPI (350 $\mathrm{nm})$ FITC (488 nm) and TRITC (594 nm) filters and a DP70 camera adapter system. As such, DAPI nuclear staining was used to ensure only viable cells were analysed, and exclude artefacts such as cell stacking within our image analysis. To assess cellular apoptosis a TUNEL assay was carried out following the manufacturer's guidelines (In situ cell death kit, Fluorescein, Roche Diagnostics).

\section{Image analysis}

CellF imaging software (Olympus Soft Imaging Solutions) was used to analyse the following islet parameters: islet-, beta- and alpha-cell areas. For transdifferentiation,

Table 1 Target, host, dilution factors and soured of primary and secondary antibodies employed for immunofluorescent studies.

\begin{tabular}{l}
\hline Target \\
\hline Primary antibodies \\
Insulin \\
Glucagon \\
GFP \\
Ki-67 \\
Pdx-1 \\
Secondary antibodies \\
IgG, Alexa Fluor 594 \\
IgG, Alexa Fluor 488 \\
IgG, Alexa Fluor 594 \\
IgG, Alexa Fluor 488 \\
IgG, Alexa Fluor 594 \\
IgG, Alexa Fluor 488 \\
IgG, Alexa Fluor 488 \\
\hline
\end{tabular}

\begin{tabular}{l}
\hline Host \\
\hline Mouse \\
Guinea-pig \\
Goat \\
Rabbit \\
Guinea-pig \\
Goat \\
Goat \\
Goat \\
Goat \\
Goat \\
Goat \\
Donkey
\end{tabular}

\begin{tabular}{l}
\hline Reactivity \\
\hline \\
Mouse \\
Mouse \\
Guinea-pig \\
Guinea-pig \\
Rabbit \\
Rabbit \\
Goat
\end{tabular}

\begin{tabular}{l} 
Dilution \\
\hline $1: 400$ \\
$1: 400$ \\
$1: 1000$ \\
$1: 500$ \\
$1: 200$ \\
$1: 400$ \\
$1: 400$ \\
$1: 400$ \\
$1: 400$ \\
$1: 400$ \\
$1: 400$ \\
$1: 400$ \\
\hline
\end{tabular}

Source

Abcam (ab6995)

Raised in-house (PCA2/4)

Abcam (ab5450)

Abcam (ab15580)

Abcam (ab47308)

Invitrogen

Invitrogen

Invitrogen

Invitrogen

Invitrogen

Invitrogen

Invitrogen 
cells expressing GFP with no insulin were termed 'insulin-ve, GFP+ve' cells, whilst islet cells co-expressing GFP with glucagon were termed 'glucagon+ve, GFP+ve" cells. To quantify apoptosis, beta- and alpha-cells co-expressing TUNEL alongside insulin and glucagon respectively were counted. Similarly, for proliferation, Ki-67 and insulinor glucagon-positive cells were recorded. To assess Pdx1 expression, the number of Pdx1/insulin-positive cells were quantified and expressed as a percentage of total insulin expressing cells. All cell counts were determined in a blinded manner with $>60$ islets analysed per treatment group.

\section{Statistics}

Results were analysed using GraphPad PRISM (version 5), with data presented as mean \pm s.E.M. Comparative analyses between groups were carried out using Student's unpaired $t$-test, one-way ANOVA with a Bonferroni post hoc test or a two-way repeated measures ANOVA with a Bonferroni post hoc test where appropriate. Results were deemed significant once $P<0.05$.

\section{Results}

Effects of STZ-, HFF- and HC-treatment alone, and in combination with liraglutide or sitagliptin administration, on body weight and energy intake in Ins1Cre/+/Rosa26-eYFP mice

All STZ mice displayed a decline $(P<0.001)$ in body weight and overall percentage body weight change, with the greatest reduction observed in the sitagliptin-treated group (Fig. 1A and B). As a result of 15 weeks of high fat feeding prior to experimentation, all HFF mice presented with increased body weight when compared to lean controls (Fig. 1D). In terms of percentage change in body weight over the 12-day treatment period, there was no difference between lean and HFF control mice, with only liraglutide significantly $(P<0.001)$ decreasing this parameter (Fig. $1 \mathrm{E})$. Body weight was reduced $(P<0.001)$ in HC-treated mice, and liraglutide or sitagliptin had no impact on this (Fig. $1 \mathrm{G}$ and $\mathrm{H}$ ). In addition, STZ mice exhibited decreased $(P<0.05-0.001)$ cumulative energy intake from day 4 onwards, with a further reduction $(P<0.05-0.001)$ evoked by treatment with liraglutide or sitagliptin (Fig. 1C). Energy intake was consistently
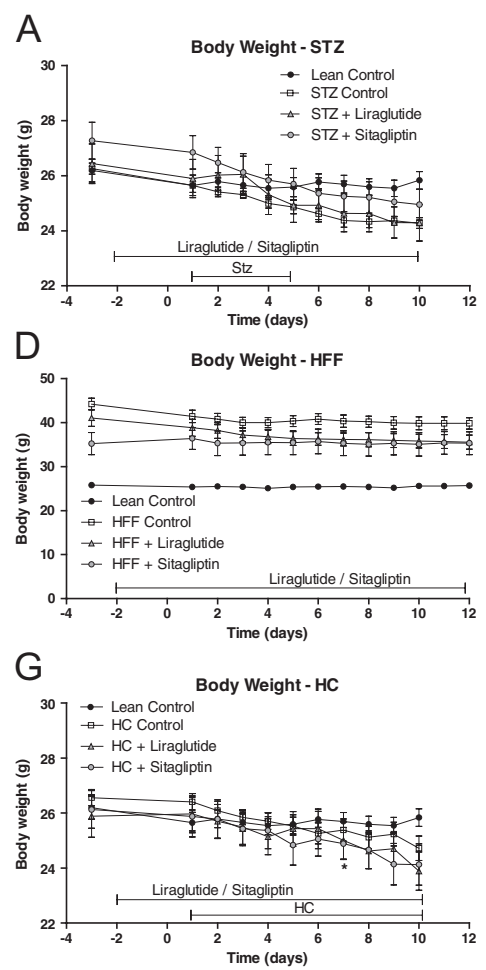

B

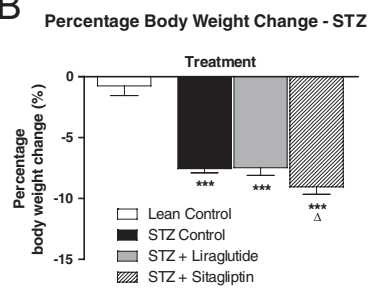

E

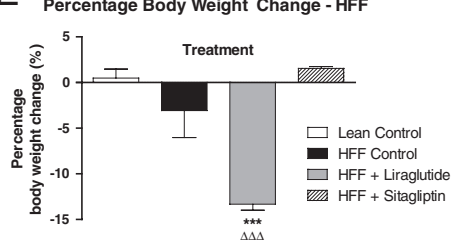

H Percentage Body Weight Change - HC

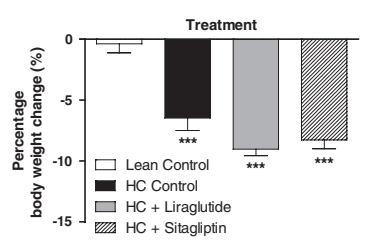

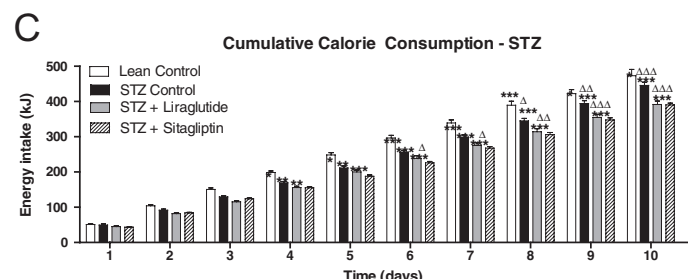

$\mathrm{F}$
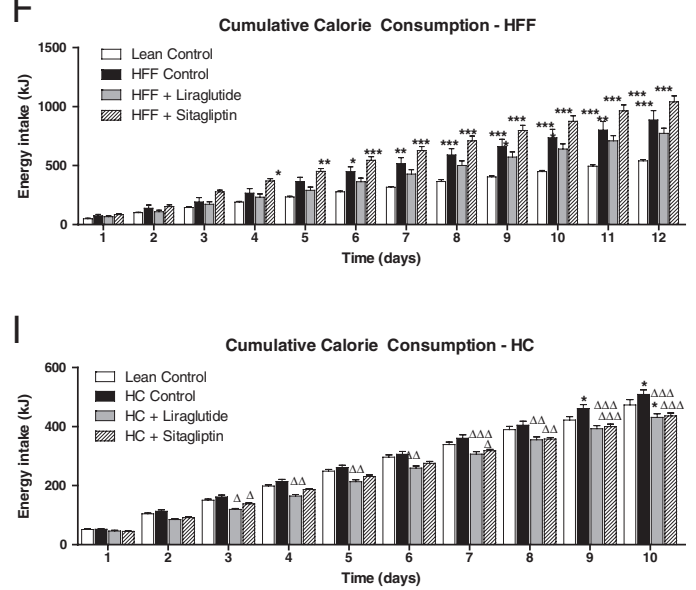

Figure 1

Effects of STZ-, HFF- and HC-treatment alone, and in combination with liraglutide or sitagliptin administration, on body weight and energy intake in Ins 1 Cre/+/Rosa26-eYFP mice. Body weight, percentage body weight change and energy intake was measured during and after 10 or 12 days, as appropriate, treatment with saline vehicle, liraglutide (25 nmol/kg bw, i.p.; B.I.D) or sitagliptin (50 mg/kg, p.o.) in (A, B, C) STZ, (D, E, F) HFF and (G, H, I) HC Ins 1 Cre/+/Rosa26-eYFP diabetic mice. Values represent mean \pm S.E.M. for six mice. ${ }^{*} P<0.05, * \star P<0.01$ and $* \star \star P<0.001$ compared to lean controls. ${ }^{\star} P<0.05$, $\Delta \Delta P<0.01 . \Delta \Delta \Delta P<0.001$ compared to respective STZ, HFF or HC controls.

https://joe.bioscientifica.com https://doi.org/10.1530/JOE-19-0451 (c) 2020 Society for Endocrinology Published by Bioscientifica Ltd. Printed in Great Britain 
increased $(P<0.05-0.001)$ in HFF mice, and liraglutide had a tendency to decrease this, but as with sitagliptin, was without significant effect (Fig. 1F). HC mice presented with significantly $(P<0.05)$ increased energy intake on days 9 and 10 , with significant $(P<0.001)$ reductions induced by both liraglutide and sitagliptin treatments (Fig. 1I).

Effects of STZ-, HFF- and HC-treatment alone, and in combination with liraglutide or sitagliptin administration, on blood glucose as well as plasma and pancreatic insulin and glucagon in Ins1Cre/+/Rosa26-eYFP mice

STZ mice exhibited increased blood glucose from day 7 onwards, attaining concentrations of $26.3 \pm 1.4$ vs $8.3 \pm 0.3 \mathrm{mmol} / \mathrm{L}$ in lean control mice by day 10 (Fig. $2 \mathrm{~A}$ ). HFF and HC mice had no substantial change in blood glucose levels (Fig. 2B, C and D). However, treatment with liraglutide or sitagliptin significantly $(P<0.05-0.001)$ reduced blood glucose levels in STZ and HC, but not HFF, mice (Fig. 2A, B, C and D). In STZ mice, plasma $(P<0.01)$ and pancreatic $(P<0.001)$ insulin were reduced, with both incretin therapies returning these parameters to lean control levels (Fig. 2E and E). High fat feeding increased $(P<0.01)$ plasma insulin (Fig. 2E), whilst both incretin therapies increased $(P<0.001)$ pancreatic insulin content in HFF mice (Fig. 2F). In HC mice, plasma and pancreatic insulin were both raised $(P<0.01)$ with sitagliptin therapy further enhancing $(P<0.05)$ plasma insulin (Fig. $2 \mathrm{E})$, and liraglutide reducing $(P<0.01)$ pancreatic insulin (Fig. $2 \mathrm{~F})$. Plasma glucagon was raised $(P<0.05-0.001)$ in all three mouse models (Fig. 2G). Liraglutide significantly $(P<0.01)$ reduced circulating glucagon levels in STZ and HFF mice, whereas sitagliptin elicited a decrease in $\operatorname{HFF}(P<0.01)$ and HC $(P<0.05)$ mice (Fig. $2 \mathrm{G})$. Similarly, liraglutide fully, and sitagliptin partially, countered the elevated glucagon in STZ diabetes (Fig. 2H). Liraglutide was also able to reduce $(P<0.01)$ pancreatic glucagon in HC mice (Fig. $2 \mathrm{H})$.
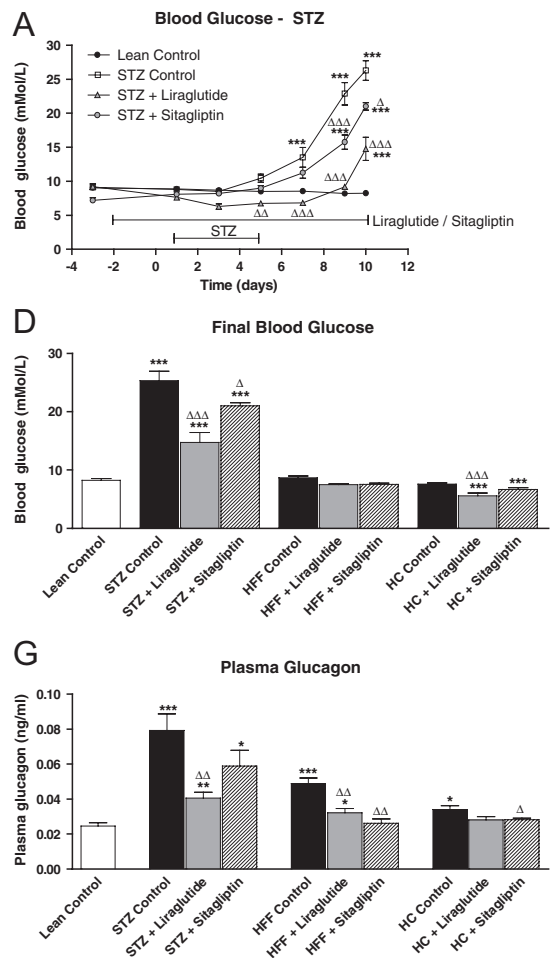

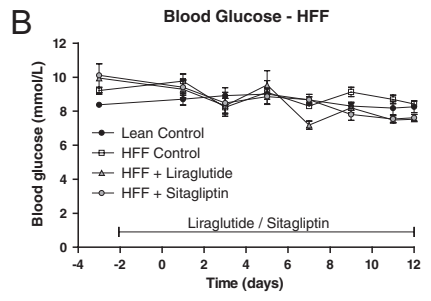

$\mathrm{E}$
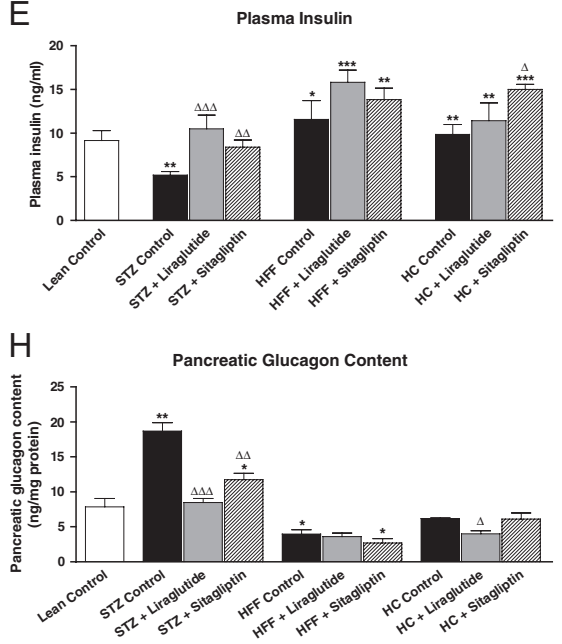
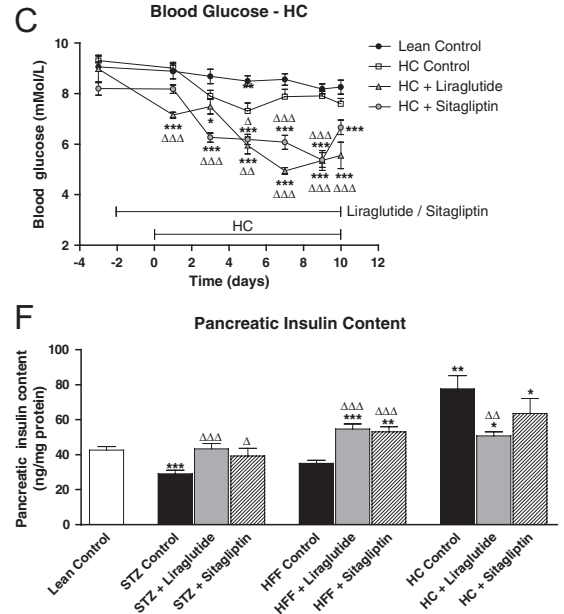

Figure 2

Effects of STZ-, HFF- and HC-treatment alone, and in combination with liraglutide or sitagliptin administration, on non-fasting circulating glucose, insulin and glucagon as well as pancreatic insulin and glucagon content in Ins 1 Cre/+/Rosa26-eYFP mice. Blood glucose was assessed in (A) STZ, (B) HFF and (C) HC Ins 1 Cre/+/Rosa26-eYFP diabetic mice for 3 days prior to, and 10 or 12 days during, as appropriate, treatment with saline vehicle, liraglutide (25 nmol/kg bw, i.p.; B.I.D) or sitagliptin (50 mg/kg, p.o.). (D, E, F, G and H) Final circulating (D) blood glucose as well as plasma and pancreatic (E and F) insulin or (G and H)

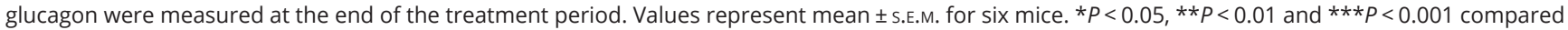
to lean controls. $\Delta P<0.05, \Delta \Delta P<0.01 . \Delta \Delta \Delta P<0.001$ compared to respective STZ, HFF or HC controls. 


\begin{tabular}{l|l|l|r|r|}
$\begin{array}{l}\text { Journal of } \\
\text { Endocrinology }\end{array}$ & N Tanday et al. & $\begin{array}{l}\text { Islet-cell transdifferentiation in } \\
\text { diabetes }\end{array}$ & $\mathbf{2 4 5 : 1}$ & $\mathbf{5 8}$ \\
\hline
\end{tabular}
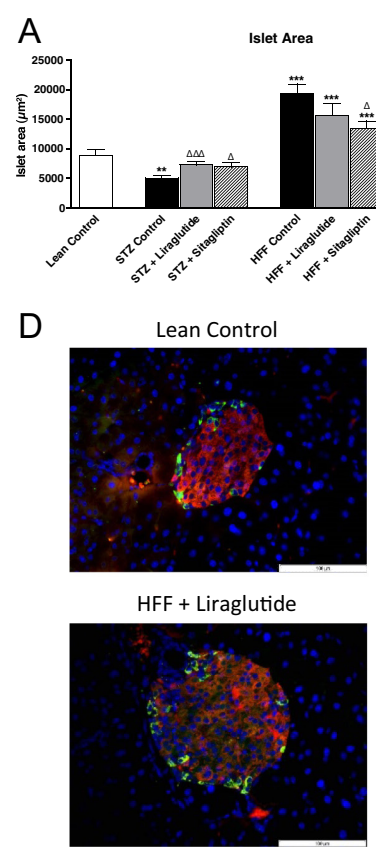

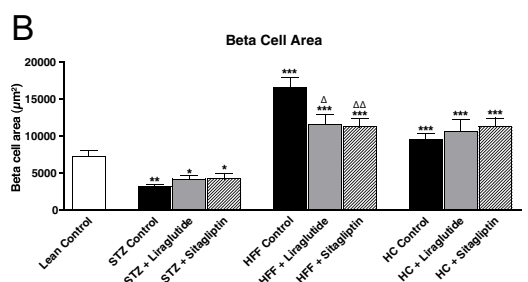

STZ Control

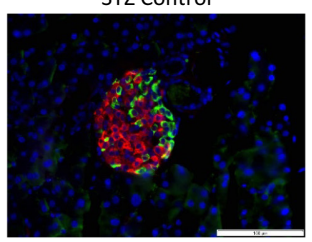

HFF + Sitagliptin

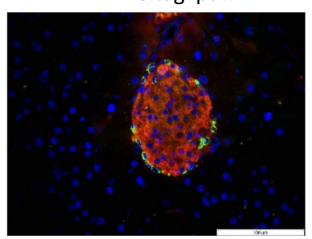

STZ + Liraglutide

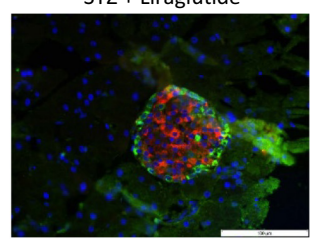

HC Control

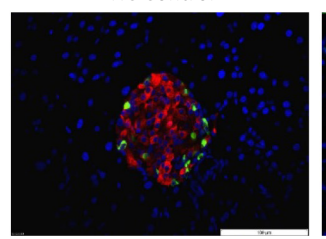

Insulin / Glucagon / DAPI

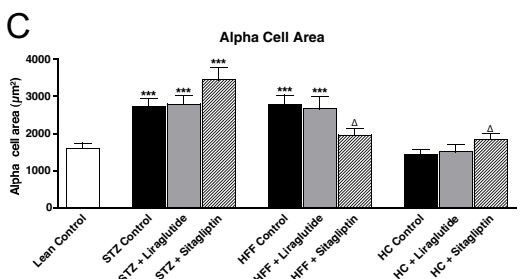

STZ + Sitagliptin

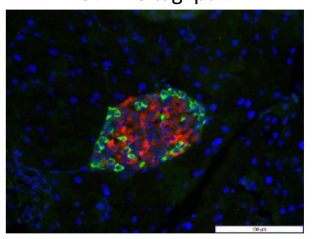

$\mathrm{HC}+$ Liraglutide
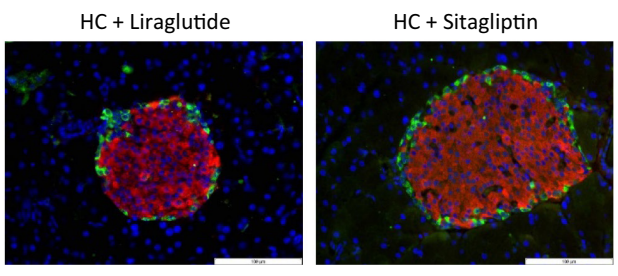

HFF Control

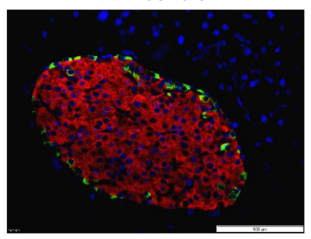

HC + Sitagliptin

Figure 3

Effects of STZ-, HFF- and HC-treatment alone, and in combination with liraglutide or sitagliptin administration, on pancreatic morphology in Ins 1Cre/t/Rosa26-eYFP mice. (A, B and C) Parameters were assessed in STZ, HFF and HC Ins 1Cre/t/Rosa26-eYFP diabetic mice after 10 or 12 days, as appropriate, treatment with saline vehicle, liraglutide (25 nmol/kg bw, i.p.; B.I.D) or sitagliptin ( $50 \mathrm{mg} / \mathrm{kg}$, p.o.). (A) Islet, (B) beta- and (C) alpha-cell areas were measured using CellF image analysis software. (D) Representative images (40x) of islets showing insulin (red), glucagon (green) and DAPI (blue) immunoreactivity from each group of mice. Values are mean \pm S.E.M. for six mice, with approximately 80 islets per group analysed. $* P<0.05, * \star P<0.01$ and $* * \star P<0.001$ compared to lean controls. $\triangle P<0.05, \triangle \Delta P<0.01$ compared to respective STZ, HFF or HC controls. A full colour version of this figure is available at https://doi.org/10.1530/JOE-19-0451.

Effects of STZ-, HFF- and HC-treatment alone, and in combination with liraglutide or sitagliptin administration, on pancreatic islet morphology in Ins1Cre/+/Rosa26-eYFP mice

STZ mice displayed reduced $(P<0.01)$ islet and beta-cell areas (Fig. $3 \mathrm{~A}$ and $\mathrm{B})$, accompanied by increased $(P<0.001)$ alpha-cell area (Fig. 3C). Islet area in liraglutide $(P<0.01)$ and sitagliptin $(P<0.05)$ treated STZ mice was elevated, despite no significant differences in alpha- or beta-cell mass (Fig. 3A, B and C). HFF mice presented with increases in islet, beta- and alpha-cell areas (Fig. 3A, B and C). Sitagliptin elicited significant $(P<0.05-0.01)$ reductions in these three islet parameters (Fig. 3A, B and C). Liraglutide treatment only reduced $(P<0.05)$ beta-cell area (Fig. $3 \mathrm{~B})$. HC mice had increased islet $(P<0.01)$ and beta-cell $(P<0.001)$ areas, with no change in alpha-cell area (Fig. $3 \mathrm{~A}, \mathrm{~B}$ and C). Liraglutide did not affect this pattern but sitagliptin treatment resulted in a small expansion $(P<0.05)$ of alpha-cell area (Fig. 3C). Representative images of pancreatic tissue stained fluorescently for insulin, glucagon and DAPI form STZ, HFF and HC diabetic mice

(C) 2020 Society for Endocrinology Published by Bioscientifica Ltd. Printed in Great Britain
Ins1Cre/+/Rosa26-eYFP mice, as well as those mice treated with liraglutide and sitagliptin, are shown in Fig. 3D.

\section{Effects of STZ-, HFF- and HC-treatment alone, and in combination with liraglutide or sitagliptin administration, on beta-to-alpha cell transdifferentiation and Pdx1 expression in Ins1Cre/+/Rosa26-eYFP mice}

All mouse models exhibited a greater $(P<0.001)$ number of insulin negative, GFP-positive cells, as well as glucagon positive, GFP-positive islet cells (Fig. 4A and B). Liraglutide significantly $(P<0.05-0.001)$ reduced numbers of both islet cell types in STZ and HFF mice, as well as glucagon positive, GFP-positive cells in HC mice (Fig. 4A and B). Sitagliptin had similar benefits in STZ mice, and also reduced $(P<0.01)$ insulin negative, GFPpositive cells in HFF mice (Fig. $4 \mathrm{~A}$ and $\mathrm{B}$ ). Induction of all forms of diabetes reduced $(P<0.001)$ Pdx1 expression in insulin-positive cells (Fig. 4C). This detrimental effect was reversed by liraglutide treatment in STZ and HC mice, and Pdx1/insulin co-staining was elevated $(P<0.05)$ by 


\begin{tabular}{l|l|l|l|l|}
$\begin{array}{l}\text { Journal of } \\
\text { Endocrinology }\end{array}$ & N Tanday et al. & $\begin{array}{l}\text { Islet-cell transdifferentiation in } \\
\text { diabetes }\end{array}$ & $\mathbf{2 4 5 : 1}$ & $\mathbf{5 9}$ \\
\hline
\end{tabular}

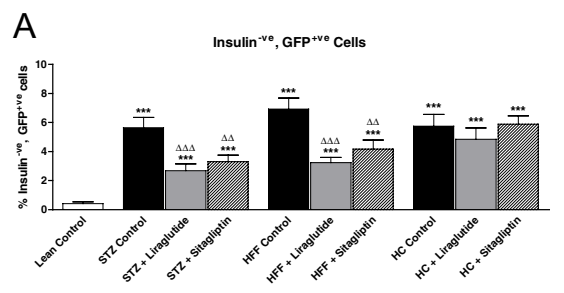

$\mathrm{D}$
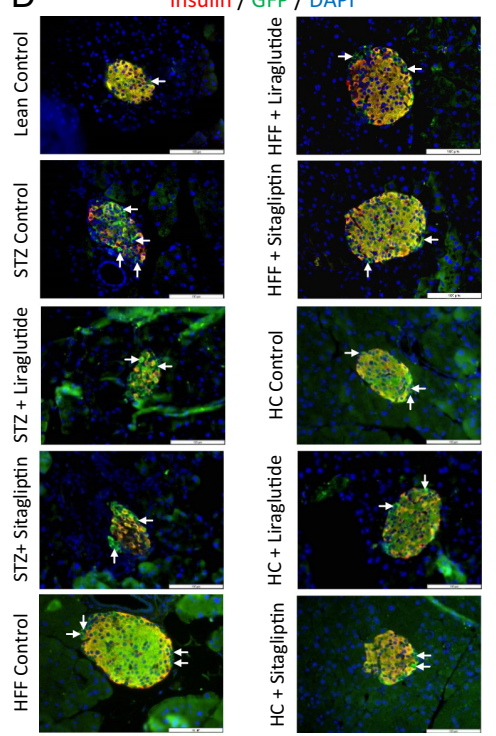

B

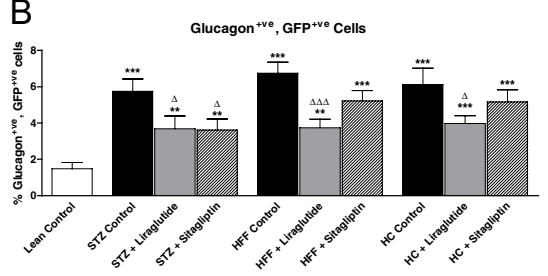

E
Glucagon / GFP / DAPI

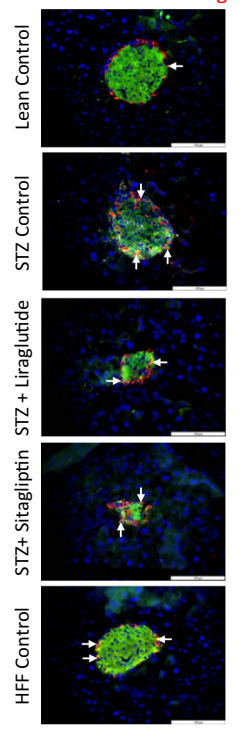

C

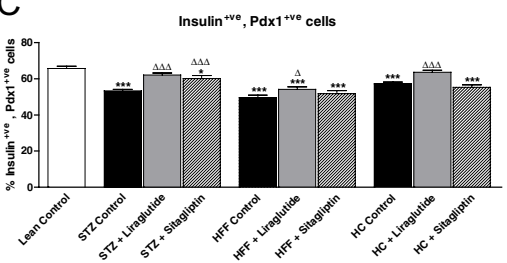

$\mathrm{F}$

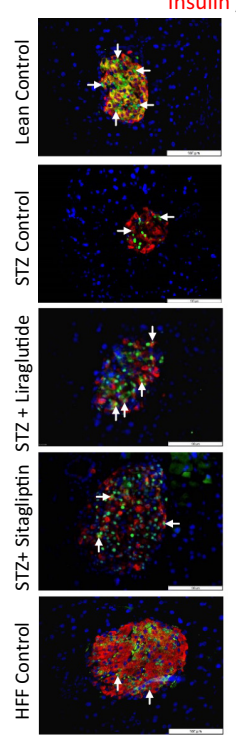

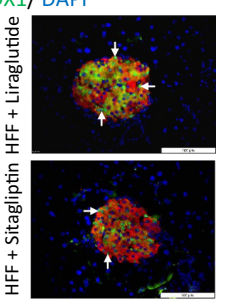
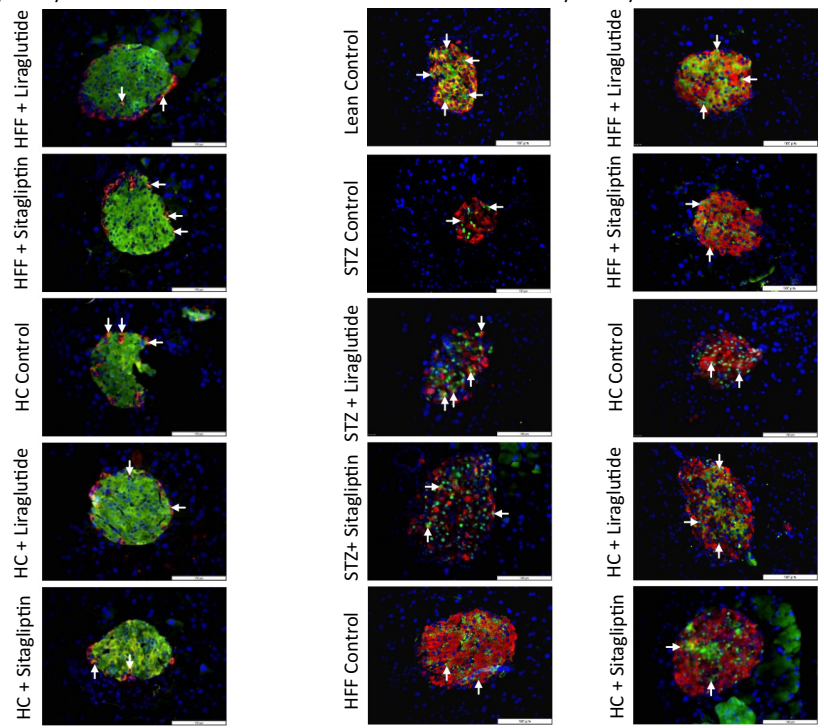

Figure 4

Effects of STZ-, HFF- and HC-treatment alone, and in combination with liraglutide or sitagliptin administration, on pancreatic beta-cell lineage and Pdx1 expression in Ins 1Cre/+/Rosa26-eYFP mice. (A, B and C) Parameters were assessed in STZ, HFF and HC Ins 1Cre/t/Rosa26-eYFP diabetic mice after 10 or 12 days, as appropriate, treatment with saline vehicle, liraglutide ( $25 \mathrm{nmol} / \mathrm{kg}$ bw, i.p.; B.I.D) or sitagliptin ( $50 \mathrm{mg} / \mathrm{kg}$, p.o.). (D, E and F) Representative images (40×) of islets showing (D) insulin (red), (E) glucagon (red) and (D and E) GFP (green), or (F) insulin (red) and Pdx1 (green) immunoreactivity from each group of mice. Arrows indicate co-staining, as appropriate. Values are mean \pm s.E.M. for six mice, with approximately 80 islets per group analysed. $* P<0.05$,

$\star \star P<0.01$ and $* \star \star P<0.001$ compared to lean controls. $\Delta P<0.05, \Delta \Delta P<0.01 . \Delta \Delta \Delta P<0.001$ compared to respective STZ, HFF or HC controls. A full colour version of this figure is available at https://doi.org/10.1530/JOE-19-0451.

liraglutide in HFF mice (Fig. 4C). Sitagliptin also increased $(P<0.001)$ Pdx1/insulin co-staining in STZ mice (Fig. 4C). Representative images of islets co-stained with insulin or glucagon and GFP, as well as Pdx1 and insulin are shown in Fig. 4D, E and F.

\section{Effects of STZ-, HFF- and HC-treatment alone, and in combination with liraglutide or sitagliptin administration on alpha- and beta-cell proliferation and apoptosis in Ins1Cre/+/Rosa26-eYFP mice}

Each mouse model exhibited increased $(P<0.05-0.001)$ beta- and alpha-cell apoptosis (Fig. 5A and B). In terms of beta-cells, liraglutide and sitagliptin therapies significantly $(P<0.05-0.001)$ reduced apoptosis in STZ, HFF and HC mice (Fig. 5A). For alpha-cells, only liraglutide reduced apoptotic cell numbers, and this was evident only in STZ $(P<0.05)$ and HC $(P<0.001)$ mice (Fig. 5B). Indeed, liraglutide returned alpha-cell apoptosis to lean control levels in STZ mice (Fig. 5B). High fat feeding $(P<0.01)$ and HC $(P<0.001)$ increased beta-cell proliferation, whereas STZ $(P<0.001)$ and high fat feeding $(P<0.05)$ increased alpha-cell growth (Fig. 6A and B). Liraglutide dramatically increased $(P<0.001)$ beta-cell proliferation in STZ mice, but lacked significant effects in HFF and HC mice (Fig. 6A). Sitagliptin did not affect beta-cell proliferation in any of the mice (Fig. 6A). However, sitagliptin did significantly decrease $(P<0.05)$ alpha-cell growth in STZ and HFF mice, whereas liraglutide was without significant effect (Fig. 6B). Representative images of islets co-stained with TUNEL and insulin (Fig. 5C) or glucagon (Fig. 5D), as well as Ki-67 with insulin (Fig. 6C) or glucagon (Fig. 6D) are also shown. 
A

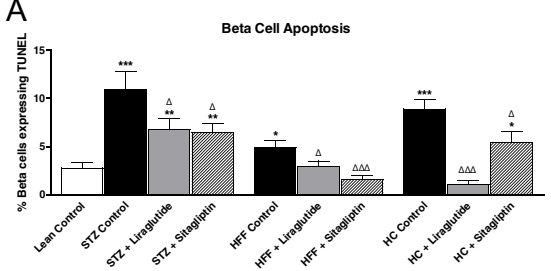

C
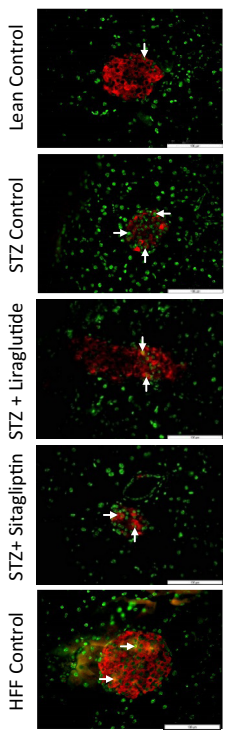

Insulin / TUNEL
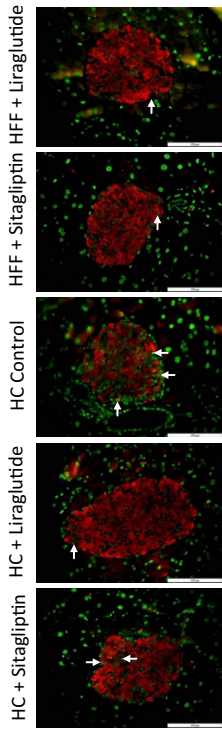

A

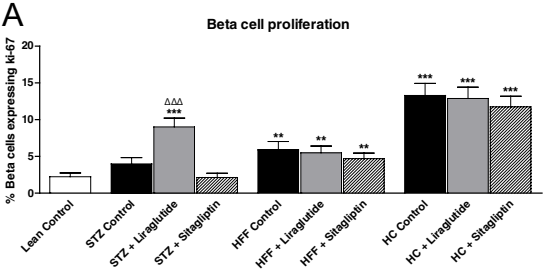

C
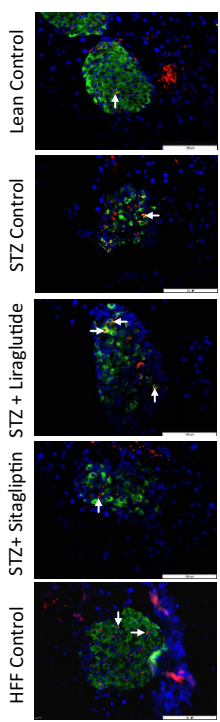
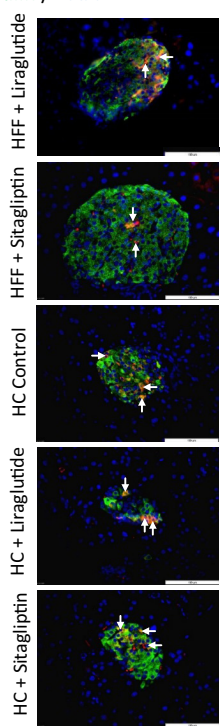

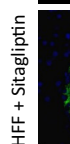

B

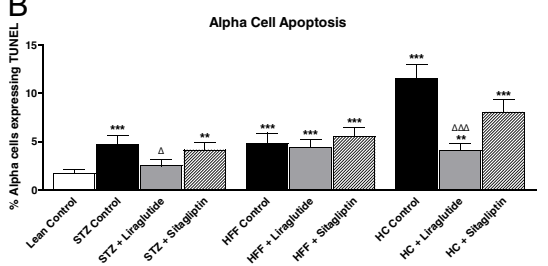

D

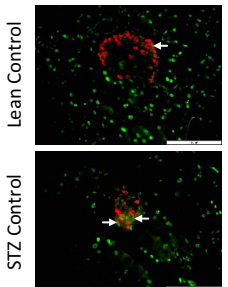

Glucagon / TUNEL
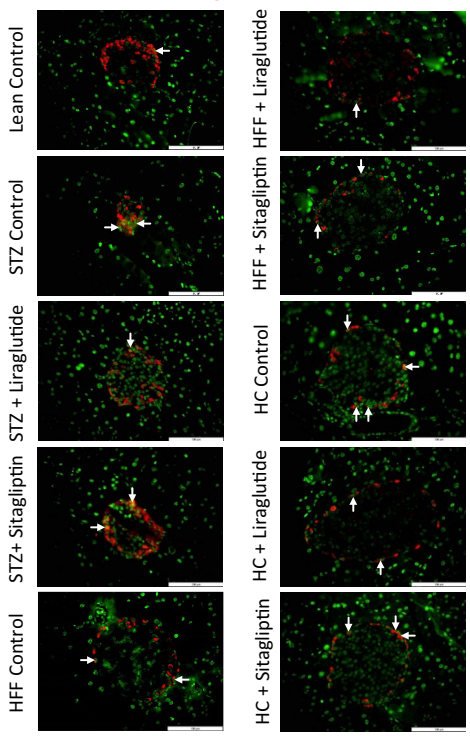

Figure 5

Effects of STZ-, HFF- and HC-treatment alone, and in combination with liraglutide or sitagliptin administration, on pancreatic beta- and alpha-cell apoptosis in Ins 1Cre/t/Rosa26-eYFP mice. (A and B) Parameters were assessed in STZ, HFF and HC Ins 1 Cre/t/Rosa26-eYFP diabetic mice after 10 or 12 days, as appropriate, treatment with saline vehicle, liraglutide ( $25 \mathrm{nmol} / \mathrm{kg}$ bw, i.p.; B.I.D) or sitagliptin (50 mg/kg, p.o.). Pancreatic (A) beta- and (B) alpha-cell apoptosis were measured using TUNEL staining and quantified with ImageJ software. (C and D) Representative images (40x) of islets showing insulin or glucagon (both green), Ki-67 (red) and DAPI (blue) immunoreactivity from each group of mice. Arrows indicate co-staining, as appropriate. Values are mean \pm S.E.M. for six mice, with approximately 80 islets per group analysed. $* P<0.05, * * P<0.01$ and $* * * P<0.001$ compared to lean controls. $\Delta P<0.05, \Delta \Delta P<0.01$. $\triangle \triangle \Delta P<0.001$ compared to respective STZ, HFF or $\mathrm{HC}$ controls. A full colour version of this figure is available at https://doi.org/10.1530/JOE-19-0451.

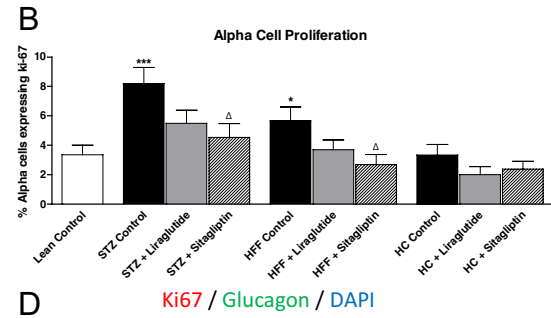

Figure 6

Effects of STZ-, HFF- and HC-treatment alone, and in combination with liraglutide or sitagliptin administration, on pancreatic beta- and alpha-cell proliferation in Ins $1 \mathrm{Cre} /+/$ Rosa26-eYFP mice. (A and B) Parameters were assessed in STZ, HFF and HC Ins 1 Cre/t/Rosa26-eYFP diabetic mice after 10 or 12 days, as appropriate, treatment with saline vehicle, liraglutide ( $25 \mathrm{nmol} / \mathrm{kg}$ bw, i.p.; B.I.D) or sitagliptin (50 mg/kg, p.o.). Pancreatic (A) beta- and (B) alpha-cell proliferation were measured using Ki-67 staining and quantified with Image software. (C and D) Representative images (40x) of islets showing insulin or glucagon (both green), Ki-67 (red) and DAPI (blue) immunoreactivity from each group of mice. Arrows indicate co-staining, as appropriate. Values are mean \pm S.E.M. for six mice, with approximately 80 islets per group analysed. $\star P<0.05, * * P<0.01$ and $* * * P<0.001$ compared to lean controls. $\Delta P<0.05, \Delta \Delta P<0.01 . \Delta \Delta \Delta P<0.001$ compared to respective STZ, HFF or HC controls. A full colour version of this figure is available at https://doi.org/10.1530/JOE-19-0451.

https://joe.bioscientifica.com https://doi.org/10.1530/JOE-19-0451 (c) 2020 Society for Endocrinology Published by Bioscientifica Ltd. Printed in Great Britain 


\section{Discussion}

All major forms of diabetes are linked to pancreatic betacell loss over time, which represents an ideal therapeutic target for this disease (Donath \& Halben 2004, Eizirik et al. 2009). In this regard, GLP-1 mimetics currently administered to T2DM patients have been shown to increase beta-cell mass in rodents through proliferation and/or neogenesis of beta-cells (Moffett et al. 2014), that is presumably linked to upregulation of important beta-cell transcription factors such as Pdx1 (Li et al. 2005, Yang et al. 2011, Gao et al. 2014). In addition, inhibition of beta-cell apoptosis is a notable feature of GLP-1 receptor activation at the level of the endocrine pancreas (Farilla et al. 2003, Moffett et al. 2014). Moreover, recent evidence suggests that GLP- 1 could augment the process of alpha- to beta-cell transdifferentiation (Zhang et al. 2019). Additional studies are required to confirm this therapeutically relevant biological action using appropriate experimental tools such as transgenic Ins $1 \mathrm{Cre} /+/$ Rosa26-eYFP mice (Thorens et al. 2015). Further to this, although the sister incretin hormone of GLP-1, namely GIP, also induces notable direct beta-cell benefits (Ehses et al. 2002, Trumper et al. 2002), there is an absence of knowledge on the impact of clinically approved DPP-4 inhibitor drugs, that augment circulating levels of GIP and GLP-1, on pancreatic islet cell transdifferentiation.

In the current study, diabetes-like syndromes with contrasting aetiologies were induced in Ins $1^{\mathrm{Cre} /+} /$ Rosa26eYFP mice, through administration of STZ, HC or prolonged high fat (45\%) feeding. These transgenic mice displayed the classic features related to either beta-cell destruction or insulin resistance (Vasu et al. 2015). As expected, the presenting metabolic characteristics and associated pancreatic morphology differed between each mouse model (Vasu et al. 2015). Thus, STZ mice exhibited hyperglycaemia-insulin deficiency, whereas HFF and HC induced marked hyperinsulinaemia-insulin resistance. All mice consistently exhibited a remarkable increase in the number of pancreatic beta-cells losing their identity, as well as the number of mature insulin-secreting beta-cells transitioning to glucagon-positive cells. There appeared to a correlation between numbers of insulin negative, GFP positive and glucagon positive, GFP-positive islet cells. This suggests that, within the limitations of immunohistochemical co-localisation, a clear islet cell transdifferentiation route seems to exist. This islet cell differentiation effect was consistently associated with decreased beta-cell Pdx1 expression. Such observations clearly indicate that beta-cell dysregulation and insulin resistance are linked to detrimental alteration of pancreatic islet cell differentiation (Talchai et al. 2012), regardless of disease pathogenesis. Given that T2DM patients have low levels of beta-cell apoptosis (Butler et al. 2003), this would suggest that the beta-cell deficit in this disease is connected to beta-cell dedifferentiation or adverse betacell transdifferentiation (Huising et al. 2018). Thus, betato alpha-cell transdifferentiation appears to be a normal phenomenon that is amplified in diabetes. The extent to which this amplification process plays in the induction and progression of diabetes still needs to be fully clarified, but our observations suggest at least some involvement. Furthermore, additional studies are required to determine whether the former beta-cells retain the beta-cell glucose sensing behaviour whilst secreting glucagon instead. These factors are of particular relevance in terms of therapeutic interventions, suggesting that antidiabetic drugs positively targeting islet cell differentiation pathways are likely to induce more effective and sustainable benefits in humans.

In all three mouse models both liraglutide and sitagliptin maintained or elevated circulating insulin and decreased plasma glucagon concentrations, while concomitantly reducing blood glucose in STZ and HC mice, in keeping with their notable antidiabetic actions (Drucker \& Nauck 2006). Lack of obvious effect of liraglutide and sitagliptin on glucose levels in HFF mice is likely related to, absence of hyperglycaemia and the timing of commencement, and duration, of the treatment interventions. As such, treatment was initiated in HFF mice following 15 weeks of high (45\%) fat feeding, where obesity, hyperinsulinaemia and related insulin resistance were already manifest. In STZ and HC mice, treatment intervention began prior to induction of the diabetes-like phenotypes. It should also be noted that both HFF and HC mice did not present with overt hyperglycaemia, and this is likely due to their prominent hyperinsulinaemia, and related elevated pancreatic beta-cell areas, that was able to offset the recognised insulin resistance in these mouse models (Vasu et al. 2015). Liraglutide was perhaps more effective in terms of correcting the changes in glucagon, glucose and insulin, and this is could be related to higher circulating GLP-1 levels induced by this treatment regimen (Ghanim et al. 2019). Indeed, the overall antidiabetic effectiveness of DPP-4 inhibitors is suggested to be slightly less striking than other clinically approved drugs (Rosenstock et al. 2010). In keeping with this, only liraglutide was able to counter weight gain induced by high fat feeding (Porter et al. 2010), with none of the https://joe.bioscientifica.com https://doi.org/10.1530/JOE-19-0451
(C) 2020 Society for Endocrinology Published by Bioscientifica Ltd.
Printed in Great Britain 
treatment interventions positively affecting body weight in STZ or HC diabetic mice. This being despite reduced energy intake in liraglutide and sitagliptin treated STZ and HC mice, and no significant impact of the treatments on energy intake in HFF mice. As such, differences in disease aetiologies (Vasu et al. 2015), and the influence and plasticity of GLP-1 receptor activation on central pathways linked to energy homeostasis (Porter et al. 2010), are likely important in accounting for such changes.

Pancreatic islet areas were retuned towards lean control levels by both incretin treatment modalities in STZ and HFF mice, consistent with established antidiabetic efficacy (Vasu et al. 2015). Interestingly, although STZ and HFF mice had elevated alpha-cell area, pancreatic glucagon concentrations were actually reduced in HFF mice, with sitagliptin inducing a further decrease in both parameters. Similarly, liraglutide and sitagliptin decreased pancreatic glucagon content, without affecting alpha-cell area, in STZ mice. Encouragingly however, both the GLP-1 mimetic and DPP-4 inhibitor drugs decreased circulating glucagon in STZ and HFF mice, in line with beneficial antidiabetic glucagonostatic effects of GLP-1 receptor activation (Lund et al. 2011). In addition, liraglutide and sitagliptin increased circulating and pancreatic insulin in both mouse models (Gault et al. 2015a, O'Harte et al. 2018), and were especially effective in STZ diabetic mice. Together with decreased glucagon, this could support the notion that incretin receptor activation may prevent or inhibit beta- to alpha-cell transdifferentiation, and foster alpha- to beta-cell transitioning.

Indeed, in STZ mice, both incretin-based treatments limited the number of islet cells converting from betato alpha-phenotypes and helped maintain beta-cell identity and maturity by upholding Pdx1 expression (Gao et al. 2014). Given the similarity in effectiveness of liraglutide and sitagliptin in this regard, it might suggest that increasing GIP alongside GLP-1 provides no additive benefit on islet cell differentiation. However, analysis of circulating concentrations of GIP and GLP-1 would be required to confirm this concept. In addition, islet alphacells are known to produce both GLP-1 and GIP under conditions of islet stress (Moffett et al. 2014) and positive effects of sitagliptin within islets cannot be ruled out. Similar favourable observations on differentiation of islet cells were also made in HFF mice treated with liraglutide and sitagliptin, albeit sitagliptin was only capable of provoking non-significant decreases in the number of beta-cells transdifferentiating towards alpha-cells and augmenting Pdx1 expression in beta-cells. Improvements in glycaemic status have been shown to prevent beta-to alpha-cell transdifferentiation as well as reversing betacell dedifferentiation (Wang et al. 2014), and importantly islet cell differentiation effects were independent of changes of circulating glucose in HFF mice. Further to this, clear benefits of liraglutide and sitagliptin to inhibit beta-cell apoptosis (Maida et al. 2009, Takeda et al. 2012), as well as promote beta-cell growth in STZ mice (Hendarto et al. 2012), could be important in terms of overall pancreatic architectural effects. However, reduced alphacell apoptosis, coupled with unaltered alpha-cell area and proliferation in liraglutide treated STZ mice, is highly suggestive of alpha- to beta-cell transdifferentiation benefits of this GLP-1 mimetic.

In $\mathrm{HC}$ mice, general pancreatic islet architecture was not remarkably altered by concurrent liraglutide or sitagliptin treatment, barring a small increase in alpha-cell area induced by the DPP-4 inhibitor drug. Interestingly, in humans DPP-4 is believed to be expressed at high levels in alpha-cells (Augstein et al. 2015), which may partly explain this finding. However, others have shown the enzyme to be readily expressed in human pancreatic beta-cells, with direct inhibition improving cell function and survival (Bugliani et al. 2018). Despite this, effects of liraglutide and sitagliptin on islet cell transdifferentiation were minimal in HC mice, aside from the GLP-1 mimetic marginally reducing diabetes-induced loss of beta-cell identity. Liraglutide substantially decreased beta-cell apoptosis in HC mice and augmented Pdx1 expression, but alpha-cell apoptosis was also reduced which may offset this benefit, especially since islet cell proliferation was unaltered by liraglutide. Thus, in this context, incretin type drugs may be less effective for cases of diabetes linked to altered glucocorticoid metabolism (Pivonello et al. 2010). However, in contrast to this notion, both incretin treatments reduced circulating glucose to levels below that of lean control mice, in keeping with knowledge that glucocorticoids can decrease GLP-1 secretion and action (Van Raalte et al. 2011).

In conclusion, the present studies highlight similar alterations of pancreatic islet cell differentiation in three well-characterised mouse models of beta-cell loss, insulin resistance and diabetes that exhibit contrasting aetiologies. As such, STZ, HFF and HC mice presented with increased beta- to alpha-cell transdifferentiation, demonstrating this process as an authentic characteristic associated with diabetes. Notably, liraglutide, and to lesser extent sitagliptin, exerted positive effects on betacell transdifferentiation particularly in STZ and HFF mice, as well as promoting growth and survival of these cells. Such actions emphasise the potential of incretin enhancer 
drugs for beta-cell restoration and subsequent promotion of enduring benefits in diabetes.

\section{Declaration of interest}

The authors declare that there is no conflict of interest that could be perceived as prejudicing the impartiality of the research reported.

\section{Funding}

These studies were supported by a Department for the Economy, Northern Ireland, PhD Research Scholarship (NT) and an early career research award from Diabetes UK to R C M. Additional support (P R F and N I) was provided by Ulster University selective research funding.

\section{Author contribution statement}

$\mathrm{N} \mathrm{I}, \mathrm{C} \mathrm{R} \mathrm{M}$ and P R F conceived the study, participated in the analysis and interpretation of data, drafted the manuscript and revised it critically for intellectual content. N T participated in the analysis and interpretation of data, drafted the manuscript and revised it critically for intellectual content. All authors approved the final version of the manuscript. N T is the guarantor of this work.

\section{References}

Accili D, Ahren B, Boitard C, Cerasi E, Henquin JC \& Seino S 2010 What ails the beta-cell? Diabetes, Obesity and Metabolism 12 (Supplement 2) 1-3. (https://doi.org/10.1111/j.1463-1326.2010.01296.x)

Augstein P, Naselli G, Loudovaris T, Hawthorne WJ, Campbell P, BandalaSanchez E, Rogers K, Heinke P, Thomas HE, Kay TW, et al. 2015 Localization of dipeptidyl peptidase-4 (CD26) to human pancreatic ducts and islet alpha cells. Diabetes Research and Clinical Practice 110 291-300. (https://doi.org/10.1016/j.diabres.2015.10.010)

Baggio LL \& Drucker DJ 2007 Biology of incretins: GLP-1 and GIP. Gastroenterology 132 2131-2157. (https://doi.org/10.1053/j. gastro.2007.03.054)

Bugliani M, Syed F, Paula FMM, Omar BA, Suleiman M, Mossuto S, Grano F, Cardarelli F, Boggi U, Vistoli F, et al. 2018 DPP-4 is expressed in human pancreatic beta cells and its direct inhibition improves beta cell function and survival in type 2 diabetes. Molecular and Cellular Endocrinology 473 186-193. (https://doi.org/10.1016/j. mce.2018.01.019)

Butler AE, Janson J, Bonner-Weir S, Ritzel R, Rizza RA \& Butler PC $2003 \beta$-Cell deficit and increased $\beta$-cell apoptosis in humans with type 2 diabetes. Diabetes $\mathbf{5 2}$ 102-110. (https://doi.org/10.2337/ diabetes.52.1.102)

Cinti F, Bouchi R, Kim-Muller JY, Ohmura Y, Sandoval PR, Masini M, Marselli L, Suleiman M, Ratner LE, Marchetti P, et al. 2016 Evidence of $\beta$-cell dedifferentiation in human type 2 diabetes. Journal of Clinical Endocrinology and Metabolism 101 1044-1054. (https://doi. org/10.1210/jc.2015-2860)

Collombat P, Hecksher-Sorensen J, Krull J, Berger J, Riedel D, Herrera PL, Serup P \& Mansouri A 2007 Embryonic endocrine pancreas and mature beta cells acquire alpha and PP cell phenotypes upon Arx misexpression. Journal of Clinical Investigation 117 961-970. (https:// doi.org/10.1172/JCI29115)

Collombat P, Xu X, Ravassard P, Sosa-Pineda B, Dussaud S, Billestrup N, Madsen OD, Serup P, Heimberg H \& Mansouri A 2009 The ectopic expression of Pax4 in the mouse pancreas converts progenitor cells into $\alpha$ and subsequently $\beta$ cells. Cell 138 449-462. (https://doi. org/10.1016/j.cell.2009.05.035)

Courtney M, Gjernes E, Druelle N, Ravaud C, Vieira A, Ben-Othman N, Pfeifer A, Avolio F, Leuckx G, Lacas-Gervais S, et al. 2013 The inactivation of Arx in pancreatic $\alpha$-cells triggers their neogenesis and conversion into functional $\beta$-like cells. PLoS Genetics 9 e1003934. (https://doi.org/10.1371/journal.pgen.1003934)

Diedisheim M, Oshima M, Albagli O, Huldt CW, Ahlstedt I, Clausen M, Menon S, Aivazidis A, Andreasson AC, Haynes WG, et al. 2018 Modeling human pancreatic beta cell dedifferentiation. Molecular Metabolism 10 74-86. (https://doi.org/10.1016/j.molmet.2018.02.002)

Donath MY \& Halban PA 2004 Decreased beta-cell mass in diabetes: significance, mechanisms and therapeutic implications. Diabetologia 47 581-589. (https://doi.org/10.1007/s00125-004-1336-4)

Drucker DJ \& Nauck MA 2006 The incretin system: glucagon-like peptide-1 receptor agonists and dipeptidyl peptidase-4 inhibitors in type 2 diabetes. Lancet 368 1696-1705. (https://doi.org/10.1016/ S0140-6736(06)69705-5)

Ehses JA, Pelech SL, Pederson RA \& McIntosh CH 2002 Glucosedependent insulinotropic polypeptide activates the Raf-Mek1/2ERK1/2 module via a cyclic AMP/cAMP-dependent protein kinase/ Rap1-mediated pathway. Journal of Biological Chemistry 277 37088-37097. (https://doi.org/10.1074/jbc.M205055200)

Eizirik DL, Colli ML \& Ortis F 2009 The role of inflammation in insulitis and $\beta$-cell loss in type 1 diabetes. Nature Reviews: Endocrinology 5 219-226. (https://doi.org/10.1038/nrendo.2009.21)

Farilla L, Bulotta A, Hirshberg B, Li Calzi S, Khoury N, Noushmehr H, Bertolotto C, Di Mario U, Harlan DM \& Perfetti R 2003 Glucagon-like peptide 1 inhibits cell apoptosis and improves glucose responsiveness of freshly isolated human islets. Endocrinology 144 5149-5158. (https://doi.org/10.1210/en.2003-0323)

Flatt PR \& Bailey CJ 1981 Abnormal plasma glucose and insulin responses in heterozygous lean (ob/+) mice. Diabetologia 20 573-577. (https:// doi.org/10.1007/bf00252768)

Gao T, McKenna B, Li C, Reichert M, Nguyen J, Singh T, Yang C, Pannikar A, Doliba N, Zhang T, et al. 2014 Pdx1 maintains $\beta$ cell identity and function by repressing an $\alpha$ cell program. Cell Metabolism 19 259-271. (https://doi.org/10.1016/j.cmet.2013.12.002)

Gault VA, Lennox R \& Flatt PR 2015a Sitagliptin, a dipeptidyl peptidase-4 inhibitor, improves recognition memory, oxidative stress and hippocampal neurogenesis and upregulates key genes involved in cognitive decline. Diabetes, Obesity and Metabolism 17 403-413. (https://doi.org/10.1111/dom.12432)

Gault VA, Martin CM, Flatt PR, Parthsarathy V \& Irwin N 2015b Xenin-25 (Lys $13 \mathrm{PAL}$ ): a novel long-acting acylated analogue of xenin-25 with promising antidiabetic potential. Acta Diabetologica 52 461-471. (https://doi.org/10.1007/s00592-014-0681-0)

Gershengorn MC, Hardikar AA, Wei C, Geras-Raaka E, Marcus-Samuels B \& Raaka BM 2004 Epithelial-to-mesenchymal transition generates proliferative human islet precursor cells. Science 306 2261-2264. (https://doi.org/10.1126/science.1101968)

Ghanim H, Green K \& Dandona P 2019 Liraglutide and dapagliflozin induce an increase in plasma GLP-1 and GLP-2 concentrations. Diabetes 68 (Suppl 1) 1034-P. (https://doi.org/10.2337/db19-1034-P)

Gu C, Stein GH, Pan N, Goebbels S, Hörnberg H, Nave KA, Herrera P, White P, Kaestner KH, Sussel L, et al. 2010 Pancreatic $\beta$ cells require NeuroD to achieve and maintain functional maturity. Cell Metabolism 11 298-310. (https://doi.org/10.1016/j.cmet.2010.03.006)

Hart AW, Mella S, Mendrychowski J, van Heyningen V \& Kleinjan DA 2013 The developmental regulator Pax6 is essential for maintenance of islet cell function in the adult mouse pancreas. PLoS ONE 8 e54173. (https://doi.org/10.1371/journal.pone.0054173)

Hendarto H, Inoguchi T, Maeda Y, Ikeda N, Zheng J, Takei R, Yokomizo H, Hirata E, Sonoda N \& Takayanagi R 2012 GLP-1 analog liraglutide protects against oxidative stress and albuminuria in streptozotocininduced diabetic rats via protein kinase A-mediated inhibition of https://joe.bioscientifica.com

https://doi.org/10.1530/JOE-19-0451
(C) 2020 Society for Endocrinology Published by Bioscientifica Ltd. Printed in Great Britain 
renal NAD(P)H oxidases. Metabolism: Clinical and Experimental 61 1422-1434. (https://doi.org/10.1016/j.metabol.2012.03.002)

Huising MO, Lee S \& van der Meulen T 2018 Evidence for a neogenic niche at the periphery of pancreatic islets. BioEssays $\mathbf{4 0}$ e1800119. (https://doi.org/10.1002/bies.201800119)

Kitamura T 2013 The role of FOXO1 in $\beta$-cell failure and type 2 diabetes mellitus. Nature Reviews: Endocrinology 9 615-623. (https://doi. org/10.1038/nrendo.2013.157)

Li Y, Cao X, Li LX, Brubaker PL, Edlund H \& Drucker DJ $2005 \beta$-Cell Pdx1 expression is essential for the glucoregulatory, proliferative, and cytoprotective actions of glucagon-like peptide-1. Diabetes $\mathbf{5 4}$ 482-491. (https://doi.org/10.2337/diabetes.54.2.482)

Lund A, Vilsbøll T, Bagger JI, Holst JJ \& Knop FK 2011 The separate and combined impact of the intestinal hormones, GIP, GLP-1, and GLP-2, on glucagon secretion in type 2 diabetes. American Journal of Physiology: Endocrinology and Metabolism 300 E1038-E1046. (https:// doi.org/10.1152/ajpendo.00665.2010)

Maida A, Hansotia T, Longuet C, Seino Y \& Drucker DJ 2009 Differential importance of glucose-dependent insulinotropic polypeptide vs glucagon-like peptide 1 receptor signaling for beta cell survival in mice. Gastroenterology 137 2146-2157. (https://doi.org/10.1053/j. gastro.2009.09.004)

Mest H \& Mentlein R 2005 Dipeptidyl peptidase inhibitors as new drugs for the treatment of type 2 diabetes Diabetologia 48 616-620.

Moffett RC, Vasu S, Thorens B, Drucker DJ \& Flatt PR 2014 Incretin receptor null mice reveal key role of GLP-1 but not GIP in pancreatic beta cell adaptation to pregnancy. PLoS ONE 9 e96863. (https://doi. org/10.1371/journal.pone.0096863)

O'Harte FPM, Parthsarathy V, Hogg C \& Flatt PR 2018 Long-term treatment with acylated analogues of apelin-13 amide ameliorates diabetes and improves lipid profile of high-fat fed mice. PLOS ONE 13 e0202350. (https://doi.org/10.1371/journal.pone.0202350)

Pivonello R, De Leo M, Vitale P, Cozzolino A, Simeoli C, De Martino MC, Lombardi G \& Colao A 2010 Pathophysiology of diabetes mellitus in Cushing's syndrome. Neuroendocrinology 92 (Suppl 1) 77-81. (https:// doi.org/10.1159/000314319)

Porter DW, Kerr BD, Flatt PR, Holscher C \& Gault VA 2010 Four weeks administration of liraglutide improves memory and learning as well as glycaemic control in mice with high fat dietary-induced obesity and insulin resistance. Diabetes, Obesity and Metabolism 12 891-899. (https://doi.org/10.1111/j.1463-1326.2010.01259.x)

Rosenstock J, Inzucchi SE, Seufert J, Fleck PR, Wilson CA \& Mekki Q 2010 Initial combination therapy with alogliptin and pioglitazone in drug-naive patients with type 2 diabetes. Diabetes Care 33 2406-2408. (https://doi.org/10.2337/dc10-0159)

Rutter GA, Pullen TJ, Hodson DJ \& Martinez-Sanchez A 2015 Pancreatic $\beta$-cell identity, glucose sensing and the control of insulin secretion. Biochemical Journal 466 203-218. (https://doi.org/10.1042/ BJ20141384)

Spijker HS, Song H, Ellenbroek JH, Roefs MM, Engelse MA, Bos E, Koster AJ, Rabelink TJ, Hansen BC, Clark A, et al. 2015 Loss of betacell identity occurs in type 2 diabetes and is associated with islet amyloid deposits. Diabetes 64 2928-2938. (https://doi.org/10.2337/ db14-1752)

Takeda Y, Fujita Y, Honjo J, Yanagimachi T, Sakagami H, Takiyama Y, Makino Y, Abiko A, Kieffer TJ \& Haneda M 2012 Reduction of both beta cell death and alpha cell proliferation by dipeptidyl peptidase- 4 inhibition in a streptozotocin-induced model of diabetes in mice. Diabetologia 55 404-412. (https://doi.org/10.1007/s00125-011-2365-4)

Talchai C, Xuan S, Lin HV, Sussel L \& Accili D 2012 Pancreatic $\beta$ cell dedifferentiation as a mechanism of diabetic $\beta$ cell failure. Cell $\mathbf{1 5 0}$ 1223-1234. (https://doi.org/10.1016/j.cell.2012.07.029)

Taylor BL, Benthuysen J \& Sander M 2015 Postnatal $\beta$-cell proliferation and mass expansion is dependent on the transcription factor Nkx6.1. Diabetes 64 897-903. (https://doi.org/10.2337/db14-0684)

Thorel F, Népote V, Avril I, Kohno K, Desgraz R, Chera S \& Herrera PL 2010 Conversion of adult pancreatic $\alpha$-cells to $\beta$-cells after extreme $\beta$-cell loss. Nature 464 1149-1154. (https://doi.org/10.1038/nature08894)

Thorens B, Tarussio D, Maestro MA, Rovira M, Heikkilä E \& Ferrer J 2015 Ins1(Cre) knock-in mice for beta cell-specific gene recombination. Diabetologia 58 558-565. (https://doi.org/10.1007/ s00125-014-3468-5)

Trumper A, Trumper K \& Horsch D 2002 Mechanisms of mitogenic and anti-apoptotic signaling by glucose-dependent insulinotropic polypeptide in beta (INS-1)-cells. Journal of Endocrinology $\mathbf{1 7 4}$ 233-246. (https://doi.org/10.1677/joe.0.1740233)

van der Meulen T \& Huising MO 2015 Role of transcription factors in the transdifferentiation of pancreatic islet cells. Journal of Molecular Endocrinology 54 R103-R117. (https://doi.org/10.1530/JME-14-0290)

Van Raalte DH, Van Genugten RE, Linssen MM, Ouwens DM \& Diamant M 2011 Glucagon-like peptide-1 receptor agonist treatment prevents glucocorticoid-induced glucose intolerance and islet-cell dysfunction in humans. Diabetes Care 34 412-417. (https://doi. org/10.2337/dc10-1677)

Vasu S, Moffett RC, McClenaghan NH \& Flatt PR 2015 Responses of GLP1-secreting L-cells to cytotoxicity resemble pancreatic $\beta$-cells but not $\alpha$-cells. Journal of Molecular Endocrinology 54 91-104. (https://doi. org/10.1530/JME-14-0214)

Wang Z, York NW, Nichols CG \& Remedi MS 2014 Pancreatic $\beta$ cell dedifferentiation in diabetes and redifferentiation following insulin therapy. Cell Metabolism 19 872-882. (https://doi.org/10.1016/j. cmet.2014.03.010)

Wei R \& Hong T 2019 Glucagon-like peptide-1 promotes alpha-to-beta cell transdifferentiation: how far is it from clinical application? Diabetes and Metabolism 45 601-602 30018-30017. (https://doi. org/10.1016/j.diabet.2019.01.003)

Weinberg N, Ouziel-Yahalom L, Knoller S, Efrat S \& Dor Y 2007 Lineage tracing evidence for in vitro dedifferentiation but rare proliferation of mouse pancreatic beta-cells. Diabetes 56 1299-1304. (https://doi. org/10.2337/db06-1654)

Weir GC \& Bonner-Weir S 2004 Five stages of evolving beta-cell dysfunction during progression to diabetes. Diabetes 53 (Suppl 3) S16-S21. (https://doi.org/10.2337/diabetes.53.suppl_3.s16)

Weir GC, Aguayo-Mazzucato C \& Bonner-Weir S $2013 \beta$-Cell dedifferentiation in diabetes is important, but what is it? Islets $\mathbf{5}$ 233-237. (https://doi.org/10.4161/isl.27494)

Yang YP, Thorel F, Boyer DF, Herrera PL \& Wright CV 2011 Contextspecific alpha- to-beta-cell reprogramming by forced Pdx1 expression. Genes and Development 25 1680-1685. (https://doi.org/10.1101/ gad.16875711)

Zhang Z, Hu Y, Xu N, Zhou W, Yang L, Chen R, Yang R, Sun J \& Chen H 2019 A new way for beta cell neogenesis: transdifferentiation from alpha cells induced by glucagon-like peptide 1. Journal of Diabetes Research 2019 2583047. (https://doi.org/10.1155/2019/2583047)

Received in final form 27 November 2019

Accepted 23 January 2020

Accepted Manuscript published online 24 January 2020 https://joe.bioscientifica.com https://doi.org/10.1530/JOE-19-0451 (c) 2020 Society for Endocrinology Published by Bioscientifica Ltd. Printed in Great Britain 